\title{
Response of Initially Stressed Concrete Targets Under High Rate of Loading
}

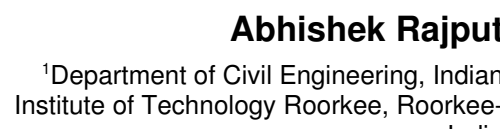

India

M.A. Iqbal

Associate Professor

Department of Civil Engineering, Indian Institute of Technology Roorkee, Roorkee-

India

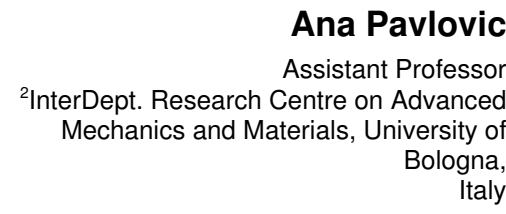

Ana Pavlovic

Assistant Professor

Italy

Prestressed concrete is a highly being used material in the construction of strategic and important structures such as nuclear containments, bridges, storage structures and military bunkers. It is highly durable, fire and corrosion resistant and nonporous. In order to study the influence of prestresing on the ballistic characteristics of concrete targets ballistic experiments have been carried out against ogival nosed (3 CRH) hard steel projectiles. The projectile of $0.5 \mathrm{~kg}$ mass were normally impacted on $80 \mathrm{~mm}$ thick presstressed concrete targets of plan size $450 \mathrm{~mm} \times 450 \mathrm{~mm}$. The unconfined compressive target strength of concrete was designed 48 MPa. An initial stress of $10 \%$ magnitude of compressive strength was induced by $4 \mathrm{~mm}$ diameter high tensile strength (1700 MPa) steel wires in prestressed concrete targets. A grid of $8 \mathrm{~mm}$ diameter steel bars were inserted in the reinforced and prestressed concrete targets to enable the straight comparison between these concretes. The prestressing in concrete has been found to be effective in reducing the volume of scabbed material as well as the ballistic resistance of prestressed concrete targets. The ballistic limit of prestressed concrete with 10\% induced stress was found to be $10.2 \%$ higher than that of the reinforced concrete and $14 \%$ higher than the plain concrete target, respectively.

Keywords Prestressed Concrete, Perforation, Scabbing, Ballistic reistance.

\section{INTRODUCTION}

The study of ballistic characteristics of plain and reinforced concrete is extremely important in order to design the important strategic structures such as, nuclear containment, bunkers, bridges, dams. The penetration mechanism of concrete barrier is relatively more complex than the metals due to its complex material behavior. During modern decades the study of the response of plain or reinforced concrete targets under ogive-nosed projectile impact has been enhanced by a number of experimental and analytical works [1-5].

A consistent improvement in strength and performance over the flast few decades transformed the concrete into most suitable construction material worldwide. Hanchak et al. [6] carried out ballistic experiments on $48 \mathrm{MPa}$ and $140 \mathrm{MPa}$ reinforced concrete targets of plan size $(610 \mathrm{~mm} \times 610 \mathrm{~mm})$ and $178 \mathrm{~mm}$ thickness against ogival nosed $0.5 \mathrm{~kg}$ projectiles. The concrete targets were reinforced by three layers of $5.69 \mathrm{~mm}$ diameter steel reinforcement grid. They concluded that an increase of compressive strength by three times, had insignificant influence on the ballistic resistance of the target. On the other hand, the ballistic experiments conducted by Shirai et al. [7] on $35 \mathrm{MPa}$ and $57 \mathrm{MPa}$ reinforced concrete targets led to the conclusion that strength plays a major role to stop the projectile penetration and scabbing of material.

Received: December 2016, Accepted: February 2017

Correspondence to: Abhishek Rajput

Department of Civil Engineering, Indian Institute of

Technology Roorkee, Roorkee-24677, India

E-mail: hiitsme.abhishek@gmail.com

doi:10.5937/fmet1704517R

(C) Faculty of Mechanical Engineering, Belgrade. All rights reserved
Hanchak et al. [6] reported that the reinforcement had an insignificant effect on the residual velocities while Haifeng and Jiangou [8] reported that dynamic load carrying capacity of reinforced concrete was significantly dependent upon the magnitude of reinforcement such that the reinforced concrete performed better than plain concrete target at higher ratios of reinforcement while an opposite trend was observed at low reinforcement ratios.

The dynamic crack propagation and impact load carrying capacity of the pre-stressed concrete railway sleepers at varying support conditions and rate of loading [9-12] have been studied under single and repeated impact loads. Under hard track condition (ballast thickness $250 \mathrm{~mm}$ ) the crack length in sleeper was found to be higher and the propagation of crack faster than in soft track condition (ballast thickness 100$150 \mathrm{~mm}$ ). Under both of these support conditions however, the failure occurred in flexure and longitudinal splitting. The pre-stressed concrete rock sheds are used in various countries to avoid casualties against falling rocks [13-14]. In an investigation of impact response of $\mathrm{T}$ and $\Gamma$ shaped pre-stressed concrete rock-sheds [14] studied through prototype experiments, the T-shaped frame has been found to rationally disperse the sectional forces over the whole structure and offered 1.7 times more resistance than $\Gamma$ shaped frame. The study of blast load resisting capacity of the concrete has demonstrated that an initial pre-stressing resulted in reduced deflections (both maximum and residual) in concrete elements, and has also been found to be effective in delaying the appearance and growth of flexural cracks [15]. Pavlovic et al. [16] performed a number of FE simulations of concrete targets against projectile impact. 
To compare the non-linear response of material, the simulations have been carried out based on RHT material models available in different commercial FEM codes. The RHT material model available in LS DYNA predicted the experiments in agreement and hence it was found most suitable model to simulating the projectile impact on concrete targets. Pavlovic and Fragassa [17] carried out finite element simulations to study the ballistic performance of flexible curtains. They confirm that the flexible curtains (PVC or PU) with height of 200, 300 and $400 \mathrm{~mm}$ may retain the 100-gram projectile upto $70 \mathrm{~m} / \mathrm{s}$ incidence velocity.

Zivkovic et al. [18] studied the influence of basalt and flax natural fiber on the impact properties under dry and salty water conditions. The hybrid (basalt/flax) composite of basalt fiber reinforcement (BFR) and flax fiber reinforcement (FFR) significantly improved the impact properties of composite in comparison to that of single composite matrix. In a further study [19] drop test were carried out on hybrid composite of basalt and flax fibers with vinylester resin to obtain the impact characteristics of composite. Further the tensile and flexural properties of the composite have acquired to model the falling weight impact response of composite. The energy dissipation also obtained through forcedisplacement curve under impact loading

A detailed modelling technique of viscoelastic response of ceramic materials using finite element codes. A time-depending problem such as viscoelasticity has merged with a temperaturedepending situation [20-21]
The present experimental investigation aims to explore the possible influence of the initially induced stress on the ballistic response of pre-stressed concrete target against projectile impact. The pre-stressed concrete plates of dimension (450 $\mathrm{mm}$ x $450 \mathrm{~mm}$ x 80 $\mathrm{mm}$ ) were subjected to $0.5 \mathrm{~kg}$ ogival nosed (3 CRH) hard steel projectiles at normal incidence.

\section{PREPARATION OF TARGET}

The concrete mix was prepared as per Indian Standard; IS10262 to obtain 28 days unconfined compressive target strength of $48 \mathrm{MPa}$. A number of trials were conducted with many configurations of cement, potable water, river sand and coarse aggregate. The final composition of the concrete mix had $440 \mathrm{~kg}$ cement, 0.4 water cement ratio, $730 \mathrm{~kg}$ river sand and $1050 \mathrm{~kg}$ coarse aggregate of size $10 \mathrm{~mm}$ in one cubic meter concrete, see Table 1 . The typical uniaxial compression tests performed on $150 \mathrm{~mm}$ cube specimens after 28 days curing in tap water resulted an average unconfined compressive strength 46-51 MPa.

The square concrete specimens of span $450 \mathrm{~mm}$ and thickness $80 \mathrm{~mm}$ were introduced a unidirectional pre-stress of $10 \%$ of unconfined compressive strength through pre-tensioning of high strength $(1700 \mathrm{MPa})$ steel wires of $4 \mathrm{~mm}$ diameter. The target was also reinforced with $8 \mathrm{~mm}$ deformed steel bars of tensile yield strength $415 \mathrm{MPa} @ 80 \mathrm{~mm}$ c/c both ways with a clear cover of $15 \mathrm{~mm}$, Fig. 1(a). The ogival nosed (3 $\mathrm{CRH}$ ) hard steel projectiles of mass $0.5 \mathrm{~kg}$ has been prepared on lathe machine, see Fig. 1(b).

Table 1. Constituents of concrete

\begin{tabular}{|ccccc|}
\hline Cement $\left(\mathrm{kg} / \mathrm{m}^{3}\right)$ & W/C ratio & Water $\left(\mathrm{kg} / \mathrm{m}^{3}\right)$ & Aggregate $\left(\mathrm{kg} / \mathrm{m}^{3}\right)$ & $\mathrm{Sand}\left(\mathrm{kg} / \mathrm{m}^{3}\right)$ \\
\hline 440 & 0.40 & 180 & 1050.4 & 730 \\
\hline
\end{tabular}

Table 2. Calculation of effective stress for inducing initial pre-stress in the target

\begin{tabular}{|c|c|c|c|c|c|c|}
\hline $\begin{array}{c}\text { Target } \\
\text { Thickness } \\
(\mathrm{mm})\end{array}$ & $\begin{array}{c}\text { Effective Cross- } \\
\text { sectional } \\
\text { Area }\left(\mathrm{mm}^{2}\right)\end{array}$ & $\begin{array}{c}\text { No. of } \\
\text { Wires }\end{array}$ & $\begin{array}{c}\text { Force in Each } \\
\text { Wire }(\mathrm{kN})\end{array}$ & $\begin{array}{c}\text { Initial Stress } \\
\text { in Target } \\
(\mathrm{MPa})\end{array}$ & $\begin{array}{c}\text { Losses (15\% of } \\
\text { Initial Stress) } \\
(\mathrm{MPa})\end{array}$ & $\begin{array}{c}\text { Effective Stress in Target } \\
(\mathrm{MPa})=\text { Initial Stress in } \\
\text { Target }- \text { Losses }\end{array}$ \\
\hline 80 & 36000 & 13 & 14 & 5 & 0.76 & 4.24 \\
\hline
\end{tabular}

(a)

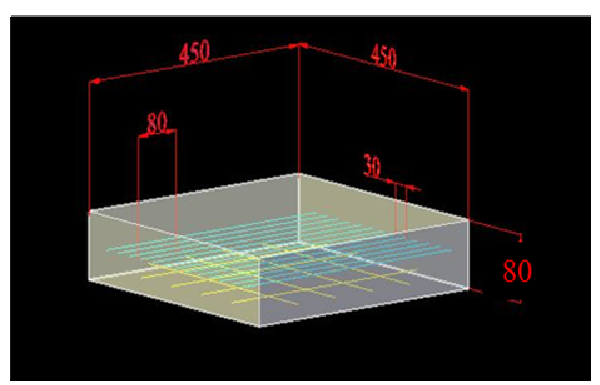

$3 \mathrm{D}$ view

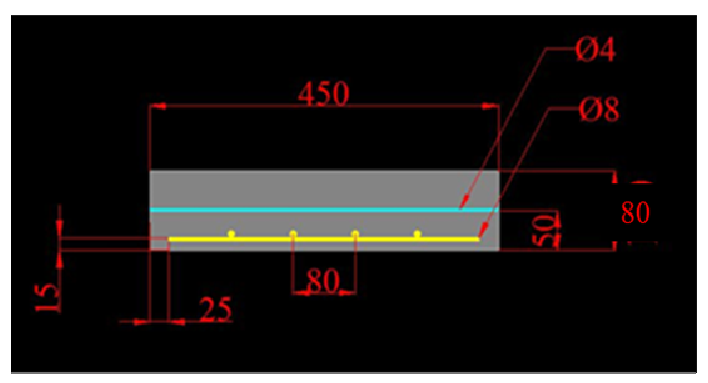

Side view

(b)

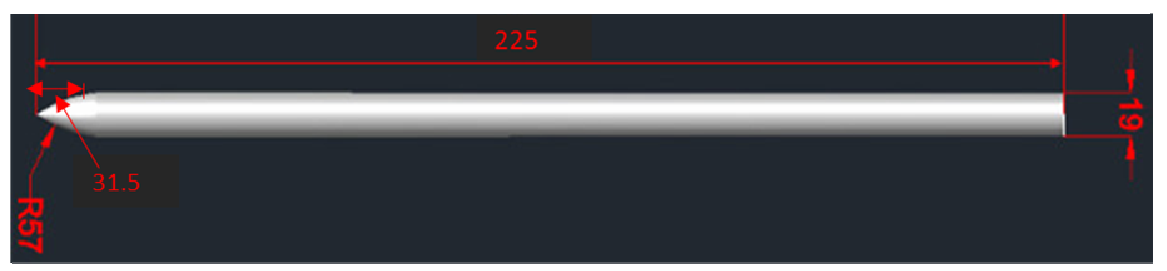

Projectile

Figure 1 Detailing of (a) pre-stressed concrete target (All dimensions in $\mathrm{mm}$ ) (b) projectile 
A total number of 13 strands were inserted in the target to induce $10 \%$ pre-stress, see Table 1. Each strand, anchored at one side and was stretched from the next end with the help of a hollow hydraulic jack. Thus, the initial stress of about 5.0 MPa was induced in the $(450 \times 450 \times 80$ $\mathrm{mm}$ ) target, at anchorage take up, see Table 1. The strands were held in position with the help of steel wedges. The total losses in pre-tress due to elastic shortening, friction, creep and shrinkage were assumed to be $15 \%$ of the initial stress (at anchorage take up) as per the recommendation of IS 1343 1980. The effective pre-stress in the target after deducing the losses was calculated to be $4.24 \mathrm{MPa}$, see Table 2. The concrete was poured in the square steel molds, compacted with the needle vibrator and the concrete surface was finished. The curing of concrete targets was done with the help of wet gunny bags for 28 days, see Fig. 2(a) and (b). The wedges were then released to transfer the stress in the concrete.

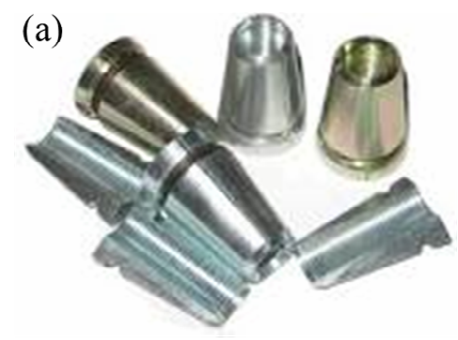

Prestressing wedges

wes

\section{BALLISTIC EXPERIMENTS}

The projectile impact experiments were conducted with the help of pneumatic gun capable to launch $0.5 \mathrm{~kg}$ projectile up to an incidence velocity $200 \mathrm{~m} / \mathrm{s}$. The length of the barrel was considered $18 \mathrm{~m}$ to enable adequate acceleration of the projectile for obtaining the required velocity. The angle of incidence was considered normal to the target. $0.5 \mathrm{~kg}$ ogival nosed hardened steel projectiles impacted on pre-stressed concrete targets at impact velocities in the range $90-$ $225 \mathrm{~m} / \mathrm{s}$. The projectile striking and residual velocities were recorded through a high speed video camera, Phantom V411. The projectile after perforation was safely collected in a robust steel box placed at $1.5 \mathrm{~m}$ behind the target. The projectile followed its central axis and struck at target center.

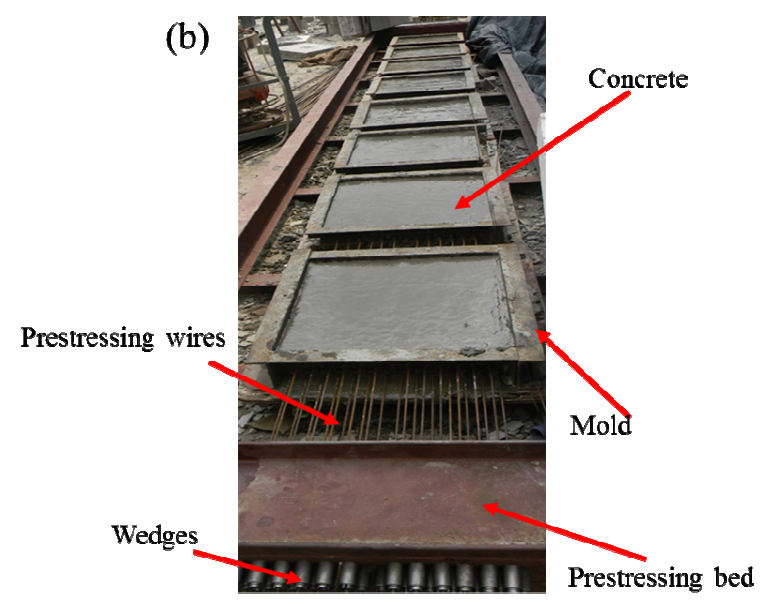

Figure 2 Details of prestressing (a) Steel wedges (b) Casting of Prestressed concrete
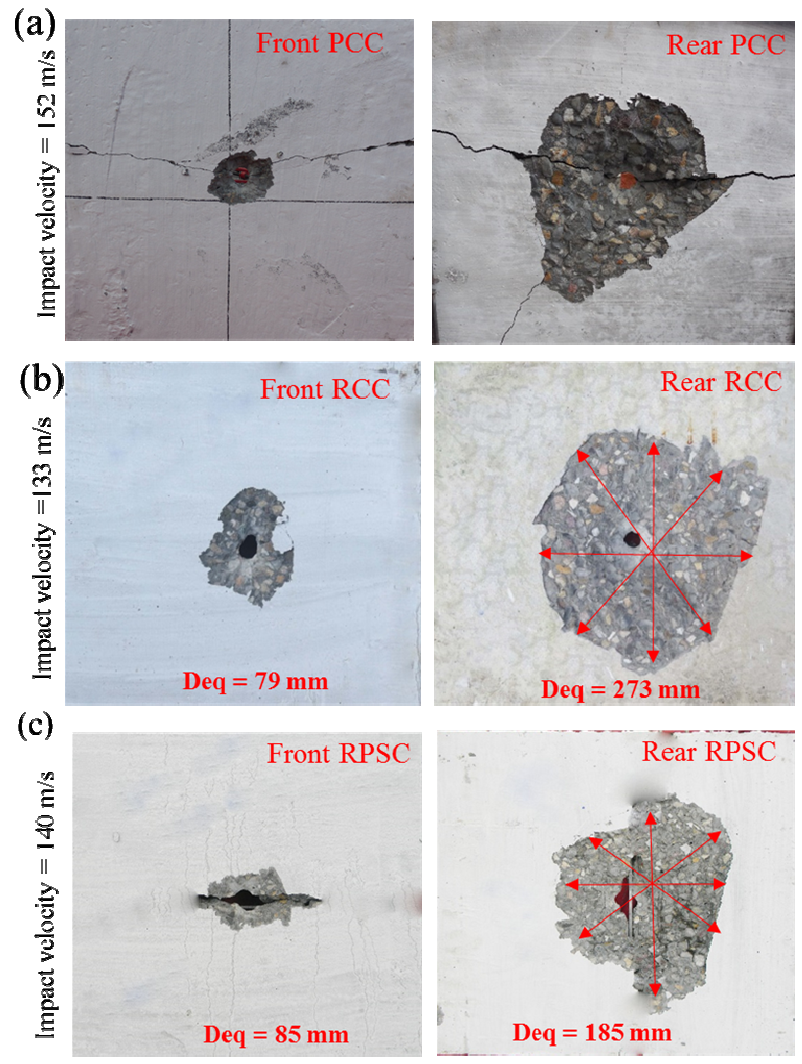

Figure 3 Tested specimens of $80 \mathrm{~mm}$ thickness (a) plain (b) reinforced and (c) prestressed concrete 
The obtained results were compared with the existing experimental findings [22]. The failure modes of the targets were found to be dependent upon the type of concrete, and the incidence velocity of projectile. The plain concrete targets experienced brittle failure. Thick radial cracks, $3-7 \mathrm{~mm}$ wide, originating from the impact location, developed across the target thickness and traversed over entire span leading to brittle failure of the target. However, there was no visible cracks could be found in the reinforced and pre-stressed concrete targets, see Fig. 3.

\section{QUANTIFICATION OF DAMAGE AND BALLISTIC RESISTANCE}

The equivalent diameter of the front and rear surface crater was acquired as the average of four diameters measured in different orientations and presented in Table 3. It has been observed that the damage at the front surface was low and its variation with respect to projectile incidence velocity and type of concrete was insignificant. The rear surface crater on the other hand had a significant influence of incidence velocity. For a given concrete, the diameter of the rear surface crater decreased with the increase in projectile velocity. For a given incidence velocity, the size of crater was found higher in case of pre-stressed concrete target followed by reinforced and plain concrete targets. However, it should be noticed that the depth of rear surface crater was found shallow (in depth) for pre-stressed concrete target.

In order to further study the extent of the damage induced in the different concrete targets, the volume of craters was obtained for each concrete target, see Table 4. The volume of spalling has been found to be relatively low and its disparity also could not be distinguished with respect to velocity and type of concrete. The volume of scabbing has been found to have major influence of incidence velocity followed type of concrete respectively, the volume of scabbing increased with the decrease in incidence velocity for a given concrete. The volume of scabbing was highest in the plain concrete followed by reinforced, $10 \%$ prestressed concrete, see Figs. 4(a)-(c).

The initial pre-stressing has proved to be effective in minimizing the damage and improving ductility of concrete. It should be noted that the damage in the target due to projectile impact occurred due to the development of tensile stresses. However, due to the induction of initial compressive stresses, the magnitude of tensile stresses reduced. Therefore, the pre-stressed concrete underwent comparatively lesser damage in comparison to reinforced and plain concrete targets.

The impact and residual velocity of projectile presented in Table 5 has been measured with the help of high speed video camera. The ballistic resistance of a given concrete has been found to be increased with the decrease in projectile incidence velocity, see Fig. 5. The increase in the target resistance with the decrease in projectile velocity was found most prominent for prestressed concrete followed by reinforced and plain concrete respectively. The ballistic limit has been obtained as the average of highest velocity giving partial penetration and the lowest velocity giving complete perforation of the target. The ballistic limit of prestressed concrete with $10 \%$ induced stress was found to be $10.2 \%$ higher than that of the reinforced concrete and $14 \%$ higher than the plain concrete target, respectively, see Table 6.

Table 3. Equivalent crater diameter in different concrete targets

\begin{tabular}{|c|c|c|c|c|c|c|c|c|c|c|c|}
\hline \multirow{2}{*}{$\begin{array}{c}\text { Target } \\
\text { Thickness } \\
(\mathbf{m m})\end{array}$} & \multirow{2}{*}{$\begin{array}{c}\text { Specimen } \\
\text { No. - impact } \\
\text { velocity }(\mathrm{m} / \mathrm{s})\end{array}$} & \multicolumn{5}{|c|}{ Front Surface } & \multicolumn{5}{|c|}{ Rear Surface } \\
\hline & & $\begin{array}{c}\text { D1 } \\
(\mathbf{m m})\end{array}$ & $\begin{array}{c}\text { D2 } \\
(\mathbf{m m})\end{array}$ & $\begin{array}{c}\text { D3 } \\
(\mathbf{m m})\end{array}$ & $\begin{array}{c}\text { D4 } \\
(\mathrm{mm})\end{array}$ & $\begin{array}{c}\text { Equivalent } \\
\text { Diameter } \\
(\mathbf{m m})\end{array}$ & $\begin{array}{c}\text { D1 } \\
(\mathbf{m m})\end{array}$ & $\begin{array}{c}\text { D2 } \\
(\mathbf{m m})\end{array}$ & $\begin{array}{c}\text { D3 } \\
(\mathbf{m m})\end{array}$ & $\begin{array}{c}\text { D4 } \\
(\mathrm{mm})\end{array}$ & $\begin{array}{c}\text { Equivalent } \\
\text { Diameter } \\
(\mathbf{m m}) \\
\end{array}$ \\
\hline 80 & PCC-160 & 64 & 89.27 & 68.85 & 87.15 & 77.31 & 240.7 & 158 & 261 & 221.4 & 220.2 \\
\hline 80 & PCC-140 & 82.4 & 65.57 & 64.8 & 78.85 & 72.90 & 161.8 & 159.5 & 175.7 & 141.0 & 159.5 \\
\hline 80 & PCC-124 & 62.4 & 71.1 & 60.75 & 61.42 & 63.91 & 170.1 & 124.8 & 152.2 & 167.2 & 153.6 \\
\hline 80 & RCC-160 & 67.2 & 82.95 & 72.9 & 92.96 & 79.00 & 195.0 & 134.3 & 208.8 & 91.84 & 157.4 \\
\hline 80 & RCC-145 & 60 & 52.93 & 64.8 & 63.08 & 60.20 & 182.6 & 135.0 & 167.0 & 188.6 & 168.3 \\
\hline 80 & RCC-140 & 88 & 78.21 & 63.18 & 73.87 & 75.81 & 187.5 & 158.0 & 179.2 & 154.1 & 169.7 \\
\hline 80 & RPSC-182 & 104 & 90.8 & 88.2 & 86.3 & 92.36 & 147.7 & 169.8 & 139.2 & 131.2 & 146.99 \\
\hline 80 & RPSC-166 & 92 & 75.8 & 72.9 & 99.6 & 85.08 & 132.8 & 189.6 & 221.8 & 196.8 & 185.26 \\
\hline 80 & RPSC-155 & 96 & 89.2 & 85.0 & 103 & 93.51 & 141.1 & 158 & 261 & 221.4 & 195.37 \\
\hline 80 & RPSC-146 & 80 & 101 & 95.5 & 107 & 96.14 & 204.1 & 189.6 & 248.8 & 170.5 & 203.29 \\
\hline
\end{tabular}

Table 4. Volume of material Eroded from different concrete targets

\begin{tabular}{|c|c|c|c|}
\hline Target Thickness $(\mathrm{mm})$ & Specimen No. & Front Surface $\left(\times 10^{3} \mathrm{~mm}^{3}\right)$ & Rear Surface $\left(\times 10^{3} \mathrm{~mm}^{3}\right)$ \\
\hline 80 & PCC-180 & 54.4 & 309.4 \\
80 & PCC-152 & 71.4 & 424.1 \\
80 & PCC-124 & 96.9 & 589.9 \\
\hline 80 & RCC-170 & 50.1 & 249.9 \\
80 & RCC-145 & 28.9 & 385.9 \\
80 & RCC-133 & 28.9 & 521.9 \\
\hline 80 & RPSC-182 & 28 & 275 \\
80 & RPSC-166 & 33 & 288 \\
80 & RPSC-155 & 44 & 313 \\
\hline 80 & RPSC-146 & 45 & 334 \\
\hline
\end{tabular}


Table 5. Incidence and residual projectile velocities for different concretes and target thicknesses

\begin{tabular}{|l|c|c|}
\hline Type of concrete & Initial velocity $(\mathrm{m} / \mathrm{s})$ & Residual velocity $(\mathrm{m} / \mathrm{s})$ \\
\hline & 180 & 76 \\
Plain Concrete (PCC) & 160 & 50 \\
& 152 & 38 \\
& 140 & 21 \\
& 124 & 0 \\
Reinforced Concrete & 170 & 59 \\
(RCC) & 160 & 42 \\
& 145 & 28 \\
& 140 & 15 \\
& 133 & 0 \\
\hline & 182 & 62 \\
Prestressed Concrete & 166 & 32 \\
(RPSC) & 155 & 14 \\
& 146 & 0 \\
\hline
\end{tabular}

Table 6. Calculated ballistic limit from the experiments

\begin{tabular}{|c|c|c|c|}
\hline $\begin{array}{c}\text { Target Thickness } \\
(\mathrm{mm})\end{array}$ & PCC & RCC & RPSC \\
\hline 80 & 132 & 136.5 & 150.5 \\
\hline
\end{tabular}

(a)

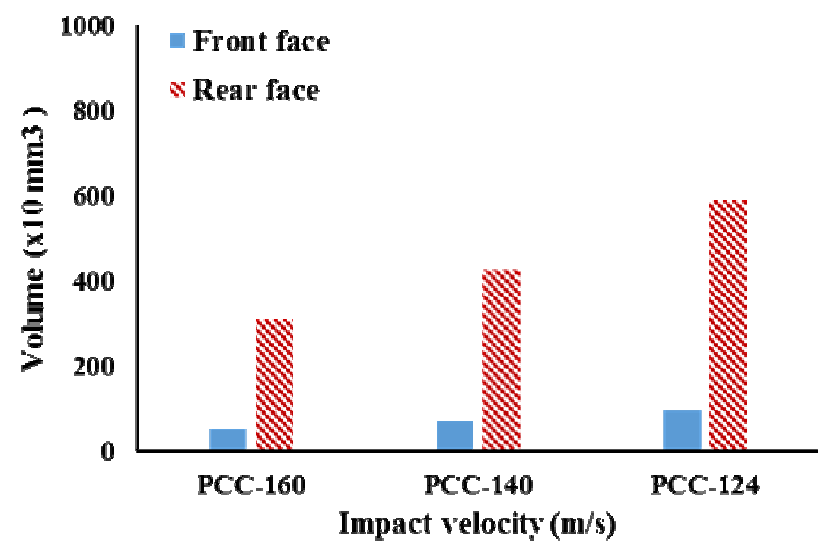

(b)

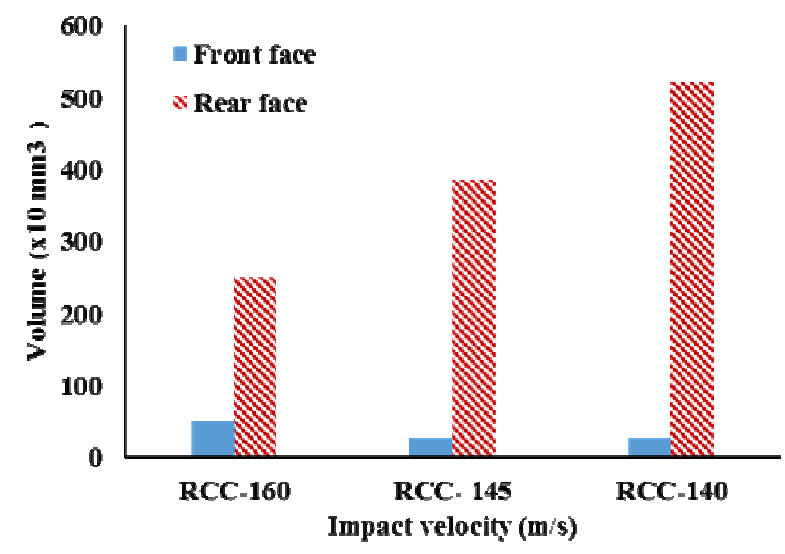

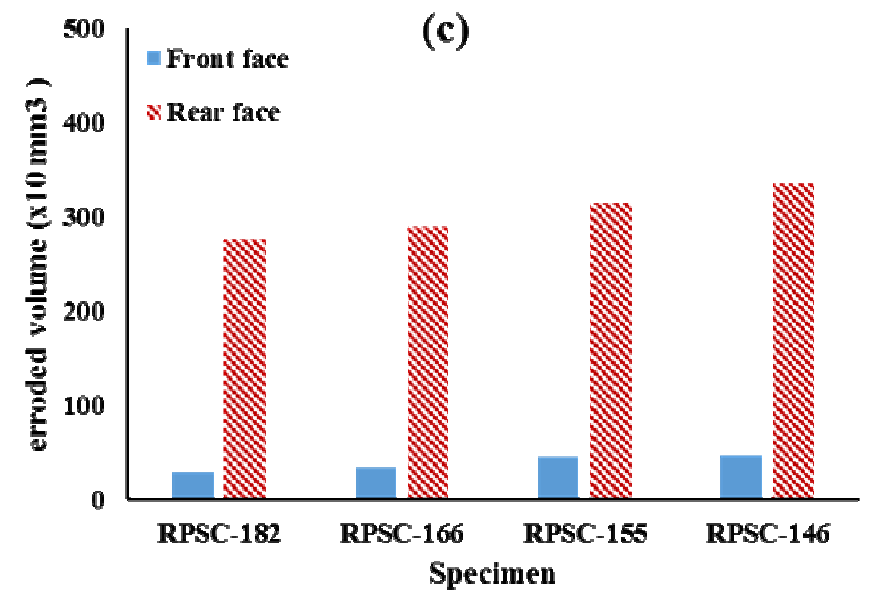

Figure 4 Scabbing and spalling of $80 \mathrm{~mm}$ thick target (a) plain (b) reinforced and (c) prestressed concrete 


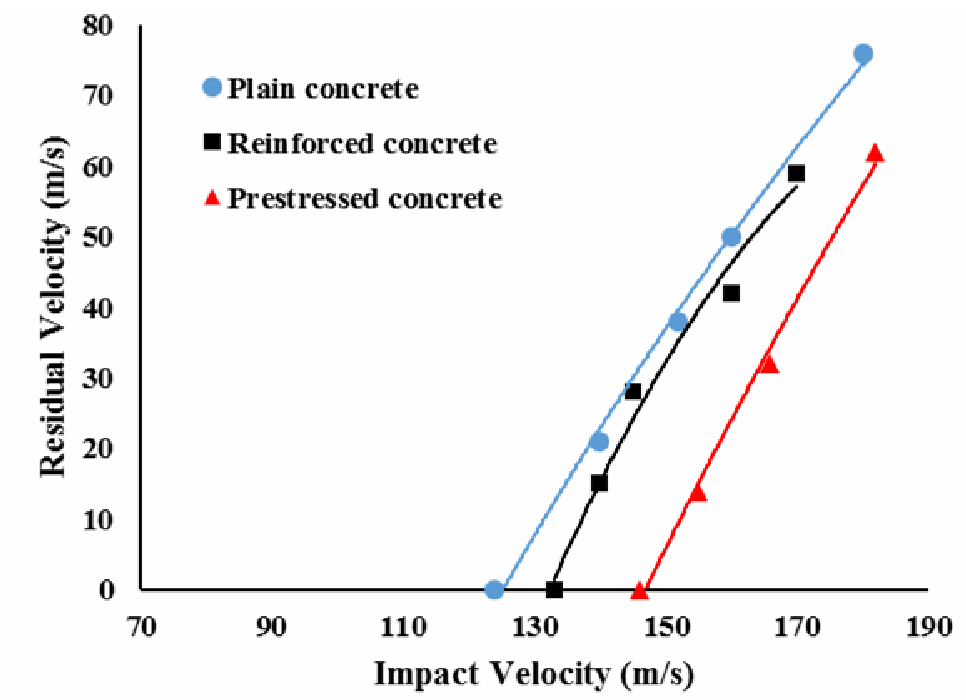

Figure 5 Ballistic performance of different type of concrete

\section{CONCLUSION}

The projectile impact experiments have been performed on the pre-stressed concrete (48 $\mathrm{MPa})$ targets and compared with the experiments earlier carried out by [22] on the plain and reinforced concrete targets. Due to the introduction of pre-stresses in the concrete plates a very huge decrease was noticed in the volume of scabbing. The initial pre-stressing has proved to be effective in minimizing the damage and improving ductility of concrete. It is found that the highest ballistic resistance was offered by the pre-stressed concrete target followed by reinforced and plain concrete targets.

\section{ACKNOWLEDGMENT}

Use the singular heading even you have many acknowledgments. Also put in this section sponsor and financial support acknowledgments.

\section{REFERENCES}

[1] Forrestal, M.J., Altman, B.S., Cargile, J.D., Hanchak, S.J., 1994. An empirical equation for penetration depth of ogive-nose projectiles into concrete targets, Int. J. Impact Eng. Vol. 15, No. 4, pp. 395-405.

[2] Li, Q.M. et al.: Local impact effects of hard missiles on concrete targets, Int. J. Impact Eng. Vol. 32, pp. 224-284, 2005.

[3] Wen, H.M., Yang, Y., A note on the deep penetration of projectiles into concrete. Int. J. Impact Eng. Vol. 66, pp. 1-4, 2014.

[4] Warren, T.L., Fossum, A.F., Frew, D.J., Penetration into low-strength (23 $\mathrm{MPa})$ concrete: target characterization and simulations. Int. J. Impact Eng. Vol. 30, pp. 477-503, 2004.

[5] Warren, T.L., Forrestal, M.J., Randles, P.W., Evaluation of large amplitude deceleration data from projectile penetration into concrete targets. Exp. Mech. Vol. 54, pp. 241-253, 2014.

[6] Hanchak S.J., Forrestal M.J., Young E.R., Ehrgott J.Q., Perforation of concrete slabs with $48 \mathrm{MPa}$ (7ksi) and $140 \quad \mathrm{MPa} \quad(20 \mathrm{ksi})$ unconfined compressive strengths. International Journal of Impact Engineering. Vol. 12, pp. 1-7, 1992.

[7] Shirai T., Kambayashi A., Ohno T., Taniguchi H., Ueda M., Ishikawa N., Experiment and numerical simulation of double-layered rc plates under impact loadings. Nuclear Engineering and Design. Vol. 176, pp. 195-205, 1997.

[8] Haifeng L., Jianguo N., Mechanical behavior of reinforced concrete subjected to impact loading. Mechanics of Materials. Vol. 41, 1298-1308, 2009.

[9] Xiang Y., Nianzhi W., Effect of loading rate and support conditions on the mode of failure of prestressed concrete railroad ties subjected to impact loading. Cement and Concrete Research, Vol. 24, No. 7, pp. 1286-1298, 1994.

[10] Kaewunruen S, Remennikov AM. Dynamic Crack Propagations in Prestressed Concrete Sleepers in Railway Track Systems Subjected to Severe Impact Loads. Journal of Structural Engineering, Vol. 136, No. 6, pp. 749-754, 2010.

[11] Kaewunruen S, Remennikov AM. Experiments into impact behaviour of railway prestressed concrete sleepers. Engineering Failure Analysis, Vol. 18, No. 8, pp. 2305-2315, 2011.

[12] Kaewunruen S, Remennikov AM. Progressive failure of prestressed concrete sleepers under multiple high-intensity impact loads. Engineering Structures, Vol. 31, No. 10, pp. 2460-2473, 2009.

[13] Ishikawa N, Katsuki S, Takemoto K. Incremental impact test and simulation of prestressed concrete beam. Structures under shock and impact VII 2002.

[14] Delhomme F., et al.: Damage mechanisms of a reinforced concrete rock-shed slab impacted by blocks. Journal of Structural Engineering, Vol. 133, pp. 1426-1433, 2007.

[15] Chen W. et al.: Numerical analysis of prestressed reinforced concrete beam subjected to blast loading. Materials and Design, Vol. 65, pp. 662-674, 2015

[16] Pavlovic A., Fragassa C., Disic A. Comparative numerical and experimental study of projectile 
impact on reinforced concrete. Composite Part B, pp. 122-130, 2017.

[17] Pavlovic A and Fragassa C. Numerical modelling of ballistic impacts on flexible protection curtains used as safety protection in woodworking. J Mechanical Engineering Science, Vol. 23, No. 1, pp. 44-58. 2017.

[18]Zivkovic Irena, Fragassa Cristiano, Pavlovic Ana, Brugo Tommaso. Influence of moisture absorption on the impact properties of flax, basalt and hybrid flax/basalt fiber reinforced green composites. Composite Part B, Vol. 111, pp. 148-164, 2017.

[19]Boria Simonetta, Pavlovic Ana, Fragassa Cristiano, Santulli Carlo. Modeling of falling weight impact behavior of hybrid basalt/flax vinylester composites Procedia Engineering, Vol. 167, pp. 223-230, 2016

[20] Fragassa Cristiano: Modelling the viscoelastic response of ceramic materials by commercial finite elements codes. FME Transactions, Vol. 44, pp. 5864. 2016.

[21] Pavlovic Ana, Fragassa Cristiano. Modelling the viscoelasticity of ceramic tiles by finite element. Pro-ceedings of the 8th Conference on Times of Polymers \& Composites. American Institute of Physics (AIP). 19-23th June 2016, Ischia (Italy). Vol. 1736, No. 4949749; doi: 10.1063/1.4949749

[22] Rajput Abhishek, Iqbal M.A., Bhargava P. Experimental and numerical study of concrete targets under high rate of loading. Procedia Engineering, Vol. 173, pp. 130 - 137, 2017.

\section{ОДГОВОР ПРЕДНАПРЕГНУТОГ БЕТОНА НА ВИСОКЕ НАПОНЕ}

\section{А. Рајпут, М. Икбал, А. Павловић}

Преднапрегнути бетон је материал са широком употребом у изградњи стратешких и важних објеката као што су нуклеарне централе, мостови, објекати за складиштење и војни бункери. Овај материајал је веома издржљив, непорозан, отпоран на ватру и корозију. У циљу испитивања утицаја преднапрезања на балистичке карактеристике бетона, балистички експерименти су спроведени са челичним пројектилом са острим врхом (3 CRH). Пројектил масе $0,5 \mathrm{~kg}$ обично су ударали на преднапрегнути бетон дебљине $80 \mathrm{~mm}$ величине 450 mm x $450 \mathrm{~mm}$. Коришћена је чврстоћа бетона на сабијање од 48MРа. Почетни напон од $10 \%$ од величине чврстоће је изазван челичном жицом пречника $4 \mathrm{~mm}$ високе затезне чврстоће (1700 Mpa) у преднапрегнутом бетону. Мрежа од $8 \mathrm{~mm}$ пречник челичних шипки је убачена у армирани и преднапрегнути бетон да би омогућила директно поређење чврстоће између ових бетона.

Утврђено је да је преднапрезање бетона ефикасно у смањењу обима красти материјала као и балистички отпор преднапрегнутог бетона. Балистичка граница преднапрегнутог бетона са $10 \%$ изазваног напона је $10,2 \%$ већа него код армираног бетона и $14 \%$ већа него у обичном бетону. 